AKRUAL 1 (2) (2010): 118-136 $e$-ISSN: 2502-6380

AKRUAL

Jurnal Akuntansi

http://fe.unesa.ac.id/ojs/index.php/akrl

\title{
PENGARUH LUAS PENGUNGKAPAN CSR TERHADAP EARNING RESPONSE COEFFICIENT PADA INDUSTRI HIGH PROFILE YANG TERDAFTAR DI PASAR MODAL
}

\author{
Rizky Eriandani \\ Universitas Surabaya \\ e-mail : rizky_eriandani@yahoo.com
}

Artikel diterima: 21 Januari 2010

Revisi terakhir: 17 Februari 2010

\begin{abstract}
The study hypothesized that CSR disclosure strengthen the association between unexpected earning and abnormal return (ERC), since CSR disclosure provide more information to interpreting accounting earning. The sample of the study is annual report 2006 of the companies listed at the Indonesian Stock Exchange, and the company is the high profile industry. This finding raises the question of whether CSR information in annual report contain value-relevant about accounting earning or if investor are simply not capable of incorporating CSR information in the firm value estimates.
\end{abstract}

Keywords : Earning Response Coefficient, CSR disclosure, High profile industry, Price to Book Value, beta.

\section{PENDAHULUAN}

Telah terjadi pergeseran paradigma dalam mengelola perusahaan, yang tadinya hanya berfokus pada shareholder, sekarang lebih berfokus pada stakeholder. Pandangan investor dalam menanamkan modal juga berubah. Investor tidak hanya mencari return yang besar tetapi juga mencari perusahaan yang bertanggung jawab terhadap lingkungan dan sosial, konsep ini dikenal dengan socially responsible investment (SRI). Kondisi ini mendorong perusahaan untuk mengungkapkan aktivitas CSR yang telah dilakukan dengan tujuan meningkatkan nilai perusahaan di mata investor.

Zuhroh dan Sukmawati (2003) menemukan bahwa pengungkapan sosial dalam laporan tahunan perusahaan yang go public berpengaruh terhadap volume perdagangan saham bagi perusahaan yang masuk kategori high profile. Perusahaan yang termasuk dalam tipe industri high profile adalah perusahaan yang memiliki tingkat sensitivitas tinggi terhadap lingkungan, sosial, tingkat resiko politik atau tingkat kompetisi yang ketat. Pentingnya suatu pengungkapan selain untuk 
meningkatkan reaksi pasar, diharapkan dapat membantu investor dalam mengintepretasikan informasi laba. Perusahaan mengharapkan dengan melakukan aktivitas CSR akan memperoleh legitimasi sosial dan memaksimalkan kekuatan keuangannya dalam jangka panjang (Kiroyan, 2006).

Gelb dan Zarowin (2000) menguji hubungan antara luas ungkapan suka-rela dengan keinformatifan harga saham. Hasil penelitian mendukung atau sesuai dengan hipotesisnya, bahwa perusahaan yang lebih banyak melakukan pengungkapan sukarela akan memiliki ERC yang lebih besar. Adhariani (2005) menghipotesiskan adanya hubungan positif antara luas ungkapan sukarela dengan ERC. ERC merupakan koefisien regresi antara abnormal return (sebagai proksi dari return) dan unexpexted earning (sebagai proksi dari laba). Hasil penelitiannya mendukung hipotesis yang dibuat, yaitu tingkat keluasan pengungkapan sukarela dalam laporan tahunan berhubungan positif dengan ERC. Widiastuti (2002) melakukan penelitian yang sama dengan ketiga penetian diatas, mengenai luas ungkapan sukarela dan ERC tetapi hipotesisnya berbeda. Hipotesisnya adalah luas ungkapan sukarela dalam laporan tahunan berpengaruh negatif terhadap ERC. Penelitian tersebut mengadopsi model Holthousen dan Verrechia (1988) yang menggunakan premis bahwa value relevance informasi laba akan semakin besar ketika terdapat ketidakpastian tentang prospek peru-sahaan di masa mendatang. Hasil penelitian menunjukkan hal yang berbeda dengan hipotesisnya, yaitu luas ungkapan sukarela berpengaruh positif dengan ERC.

Sayekti dan Wondabio (2007) menguji pengaruh CSR Disclosure terhadap Earning Response Coefficient. Penelitian tersebut menggunakan teori yang sama dengan Widiastuti (2002), tetapi menggunakan luas ungkapan CSR (yang merupakan salah satu bentuk ungkapan sukarela) sebagai proksi ketidakpastian prospek perusahaan di masa mendatang. Hasil penelitian tersebut sesuai dengan hipotesisnya, bahwa luas ungkapan CSR berpengaruh negatif terhadap ERC.

Bangh $\varnothing \mathrm{j}$ dan Plenborg (2008) menguji apakah semakin luas pengungkapan sukarela dalam laporan tahunan akan mengurangi asimetri informasi antara perusahaan dan investor di Denmark, asimetri informasi diproksi dengan hubungan return dan laba (ERC). Hasilnya, bahwa luas ungkapan sukarela meningkatkan respon investor terhadap laba, tetapi tidak signifikan. Salah satu penjelasan yang diajukan dalam menjawab hasil penelitian tersebut adalah investor tidak mampu menggunakan informasi sukarela dalam mengestimasi nilai perusahaan.

Penelitian-penelitian diatas menunjukkan ketidakkonsistensian hasil. Oleh karena itu, Penelitian ini akan menguji apakah pengungkapan CSR sebagai salah satu bentuk pengungkapan sukarela, akan meningkatkan respon investor terhadap laba (ERC). Hubungan return dan earning atau respon investor terhadap laba diproksi dengan earning response coefficient (ERC). Koefisien respon laba atau ERC didefinisikan sebagai ukuran atas tingkat return abnormal saham dalam merespon komponen unexpected earnings (Scott, 2006). Semakin besar perubahan dalam unexpected earnings, maka akan semakin besar respon pasar sekuritas. Penelitian ini menggunakan data tahun 2006, karena sampai tahun 2006 pengungkapan CSR masih 
bersifat sukarela (voluntary disclosure), sedangkan setelah 2006 pengungkapan CSR sudah bersifat mandatory (diatur pada UU PT No.40 Pasal 74 tahun 2007). Pengungkapan CSR dalam penelitian ini berperan sebagai variabel moderating antara variabel unexpected earning dengan abnormal return.

Penelitian ini bertujuan mengetahui dan menganalisis pengaruh luas pengungkapan CSR terhadap ERC, dan secara tidak langsung dapat membuktikan bahwa dengan adanya informasi lain, dalam penelitian ini luas pengungkapan CSR, dapat menyebabkan meningkatnya respon terhadap informasi laba. Target populasi dalam penelitian ini adalah semua emiten-emiten yang terdaftar di Bursa Efek Indonesia pada 2006 dan telah mempublikasikan annual report pada tahun yang sama, yaitu sebanyak 343 emiten. Dengan menggunakan purposive sampling, didapatkan sampel penelitian sebesar 109 emiten.

Respon investor terhadap laba diamati dalam window period tertentu. Penelitian ini menggunakan window period 60 hari, karena di Indonesia batas penyampaian laporan keuangan dan laporan tahunan adalah 3 bulan setelah akhir periode sampai 60 hari sesudah-nya yaitu 1 April 2009 sampai 30 Juni 2009. Penggunaan periode 60 hari karena pasar membutuhkan waktu untuk mengintepretasikan informasi yang diterima, mengantisipasi post earning announcement. Tidak digunakan periode selama satu tahun, karena dikuatirkan bias dengan adanya informasi lainnya.

\section{KAJIAN PUSTAKA}

Berdasarkan APB 1970 No. 4 paragraf 10, laporan keuangan adalah alat yang mengakomodasi dan memproses informasi ke dalam akuntansi keuangan yang secara periodik dikomunikasikan kepada penggunanya. SFAC no. 1 paragraf 6 menyatakan bahwa laporan keuangan merupakan hal utama dalam pelaporan keuangan, dan paragraf 7 menyebutkan bahwa pelaporan keuangan (financial reporting) tidak hanya terdiri dari laporan keuangan, tetapi meliputi informasi lainnya (financial \& non financial) yang terkait. Misalnya, laporan forecast management, pengungkapan dampak sosial dan lingkungan dari perusahaan, dan sebagainya.

Dua tipe pengungkapan yang terdapat dalam annual report (Myburgh, 2001), yaitu mandatory disclosure dan voluntary disclosure. Mandatory disclosure merupakan item-item informasi yang wajib diungkapkan oleh perusahaan yang diminta oleh undang-undang, pasar modal, atau yang telah ditetapkan dalam standar akuntansi. Voluntary disclosure merupakan pengungkapan informasi melebihi dari peraturan yang berlaku. Pengungkapan yang dilakukan diharapkan dapat mengurangi information asymmetry, dimana salah satu pihak memiliki informasi lebih dibanding pihak lainnya.

Pengungkapan aktivitas CSR sebagai salah satu bentuk pengungkapan sukarela dipandang sebagai komitmen bisnis untuk memberikan kontribusi bagi pembangunan ekonomi berkelanjutan, melalui kerjasama dengan para karyawan serta perwakilan mereka, keluarga mereka, komunitas setempat maupun masyarakat umum untuk meningkatkan kualitas hidup, dengan cara-cara yang bermanfaat baik bagi bisnis itu sendiri, maupun untuk pembangunan (Kiroyan, 2006). 
Pengukuran luas pengungkapan CSR sukarela dalam laporan tahunan dilakukan dengan membandingkan antara skor total pengungkapan perusahaan dengan skor pengungkapan maksimum yang dapat dicapai oleh suatu perusahaan. Pemilihan item pengungkapan didasarkan pada daftar item pengungkapan yang dikembangkan oleh Hackston and Milne (1996), yang kemudian dikembangkan dan disesuaikan dengan kondisi di Indonesia oleh Sembiring (2005). Pengukuran variabel pengungkapan informasi CSR atau CSR disclosure index (CSDI) dilakukan dengan cara content analysis yang mengukur variasi dari CSRI (Sayekti dan Wondabio, 2007). Metode content analysis digunakan untuk mengukur kuantitas dan kualitas pengungkapan. Kuantitas pengungkapan informasi lingkungan dan sosial dalam banyak hal menunjukkan pentingnya suatu informasi tersebut diungkapkan, artinya semakin banyak suatu item informasi diungkapkan berarti semakin penting informasi tersebut (Neu et al., 1998; Stagliano dan Walden, 1998 dalam Sudarno, 2004).

Koefisien respon laba atau ERC didefinisikan sebagai ukuran atas tingkat return abnormal saham dalam merespon komponen unexpected earnings (Scott, 2006). Semakin besar perubahan dalam unexpected earnings, maka akan semakin besar respon pasar sekuritas. Earnings Response Coefficients mengukur pengaruh dari satu dolar laba kejutan terhadap return saham, dan diukur sebagai slope dalam regresi return abnormal saham dan unexpected earnings (Cho dan Jung, 1991 dalam Suaryana, 2005:149).

Tiga tahap perhitungan untuk mem-peroleh nilai ERC. Pertama, menghitung CAR masing-masing emiten sampel. Kedua, menghitung UE masing-masing sampel. Ketiga, menghitung regression coefficient slope antara CAR sebagai variabel independen dan UE sebagai variabel dependen. Beberapa faktor yang mempengaruhi besarnya respon investor terhadap informasi laba adalah Beta, Persistensi laba dan kualitas laba, persistensi, kesempatan bertumbuh, dan keinformatifan harga saham.

Pengelompokkan industri berdasarkan kerentananya dalam isu sosial dan lingkungan dilakukan oleh Hackston dan Milne (1996:87) adalah tipe industri high profile dan low profile. Perusahaan yang termasuk dalam tipe industri high profile adalah perusahaan yang memiliki tingkat sensitivitas tinggi terhadap ling-kungan, tingkat resiko politik atau tingkat kompetisi yang ketat.

Tabel 1. Kategori Industry High Profile Penelitian Terdahulu

\begin{tabular}{ll}
\hline & High Profile \\
\hline Perminyakan dan Pertambangan & Tembakau dan Rokok \\
Kimia & Produk makanan dan minuman \\
Hutan & Media dan Komunikasi \\
Kertas & Energi (listrik) \\
Otomotif & Engineering \\
Penerbangan & Kesehatan \\
Agribisnis & Transportasi dan Pariwisata \\
\hline
\end{tabular}

Sumber : Hackston and Milne (1996) dan Sembiring (2005) 


\section{Pengembangan Hipotesis}

Besarnya kekuatan hubungan laba dengan harga saham dalam literatur akuntansi dan keuangan diukur dengan menggunakan ERC (Beaver, 1998:103, dalam Riduwan, 2004:213). Penelitian ini, mencoba menjelaskan pengaruh luas pengungkapan CSR terhadap koefisien respon laba dalam industri high profile, yang dapat digambarkan sebagai berikut:

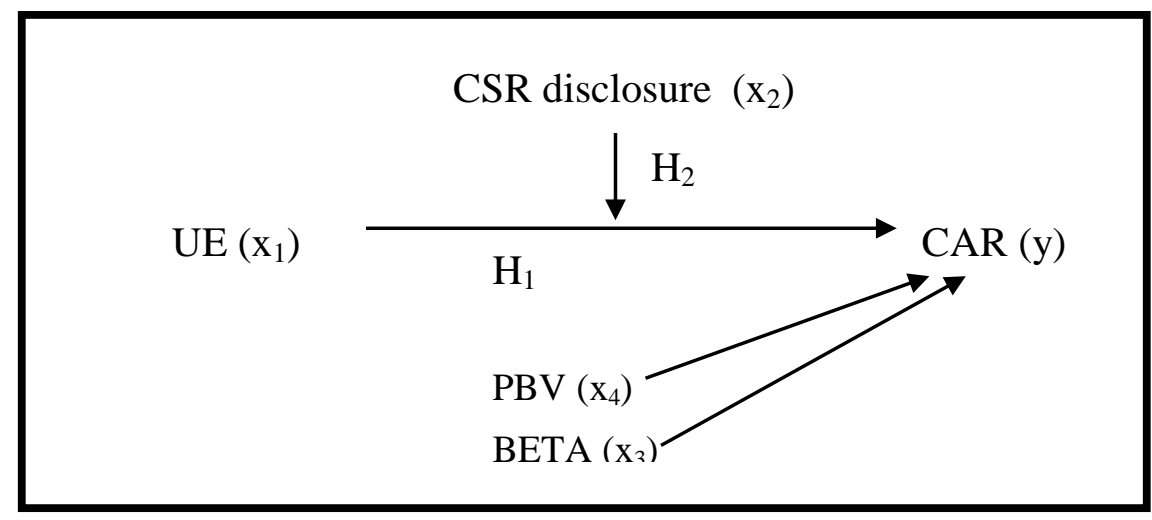

Sumber: Data olahan

\section{Gambar 1. Model Penelitian}

Ball dan Brown (1968) menemukan bahwa informasi yang terkandung dalam angka akuntansi adalah berguna jika laba yang sesungguhnya berbeda dengan laba ekspektasi (expected earning). Harga saham cenderung naik apabila laba yang dilaporkan lebih besar daripada laba eks-pektasi dan sebaliknya, harga saham cenderung turun apabila laba yang dilaporkan lebih kecil daripada laba ekspektasi. Dengan demikian, rumusan hipotesis pertama adalah sebagai berikut :

\section{$\mathrm{H}_{1}$ : Unexpected earning berpengaruh positif terhadap abnormal return.}

Penelitian yang dilakukan oleh Sayekti dan Wondabio (2007) mengenai pengaruh pengungkapan CSR dan earning response coefficient menunjukkan adanya hubungan negatif antara ke-duanya. Bangh $\varnothing_{\mathrm{j}}$ dan Plenborg (2008) menemukan bahwa pengungkapan sukarela dalam laporan tahunan mempengaruhi hubungan return dan laba secara positif, tetapi tidak signifikan. Hubungan return dan laba dapat digunakan sebagai proksi asimetri informasi. Rendahnya hubungan return dan laba mengindikasikan bahwa hanya sedikit informasi mengenai nilai perusahaan yang tercermin dari informasi laba, berarti terjadi asimetri yang tinggi (Lang and Lundholm, 1993). Sifat perusahaan high profile yang lebih banyak menghadapi tekanan dari berbagai aspek (Robert, 1992:605 dalam Hackston dan Milne, 1996), menyebabkan investor tidak bisa hanya fokus pada laporan earning perusahaan. Dengan adanya pengungkapan sosial yang luas, investor akan memperhatikan 
informasi tersebut karena akan membantu investor membuat ekspektasi, dan membuat investor lebih bereaksi terhadap unexpected earning; sehingga di-harapkan pengungkapan CSR tersebut dapat meningkatkan respon investor terhadap informasi laba. Oleh karena itu, hipotesis kedua yang diajukan dalam penelitian ini adalah :

\section{$\mathrm{H}_{2}$ : Luas pengungkapan CSR dalam laporan tahunan, akan memperkuat respon investor terhadap laba.}

\section{METODE PENELITIAN}

Penelitian ini menggunakan data sekunder yang diperoleh dari laporan tahunan perusahaan yang terdaftar di Bursa Efek Indonesia (BEI) untuk tahun yang berakhir 31 Desember 2006. Dari 343 perusahaan yang terdaftar tahun 2006, sampel penelitian ini menggunakan 109 perusahaan. Pengambilan sampel dalam penelitian ini dilakukan dengan cara non-probability sampling, dengan teknik purposive (judgment) sampling.

\section{Tabel 2. Pemilihan Sampel}

\begin{tabular}{lr}
\hline \multicolumn{1}{c}{ Kriteria Sampel } & Jumlah \\
\hline Total populasi & 343 \\
Tidak termasuk industry high profile & $(205)$ \\
Data penelitian tidak lengkap & $(23)$ \\
Rasio PBV bernilai negative & $(3)$ \\
Data outliers & $(3)$ \\
& Total Sampel \\
\hline
\end{tabular}

Sumber : data olahan

Industri yang termasuk high profile dalam penelitian ini adalah Agriculture, Forestry and Fishing; Mining and Mining service; Food and Beverage; Tobacco Manufactures; Lumber and woods products; Paper and Allied Products; Cables; Adhesive; Electronic and Office equipment; Automotive and Allied products; Pharmaceuticals; Transportation Services; Telecommunication; Hotel and Travel services; Chemical and allied product; dan Metal and allied products. Variabel dependen dalam penelitian ini adalah Cummulative Abnormal Return (CAR) dan. Kemudian, Unexpected Earnings (UE) sebagai variabel independen yang mempengaruhi CAR. luas pengungkapan CSR atau CSDI berfungsi sebagai variabel moderating antara variabel UE dengan CAR. Istilah luas pengungkapan CSR digunakan pada saat pembahasan penelitian, sedangkan istilah CSDI digunakan dalam model analisis untuk pengujian hipotesis. Variabel Price to Book Ratio (PBV) dan BETA dalam penelitian ini sebagai variabel control.

Untuk menguji hipotesis yang diajukan, digunakan alat uji analisis regresi berganda dengan model interaksi. Penelitian ini mengajukan tiga model, model pertama akan menjelaskan apakah CAR berhubungan dengan unexpexted earning 
(UE); model kedua dan ketiga digunakan untuk menguji apakah luas pengungkapan CSR sebagai variabel pure moderator, quasi moderator, atau independent predictor. Model ketiga juga akan menjelaskan luas pengungkapan CSR akan memperkuat hubungan CAR dan UE (meningkatkan respon terhadap informasi laba). Model analisis yang digunakan untuk pengujian hipotesis adalah :

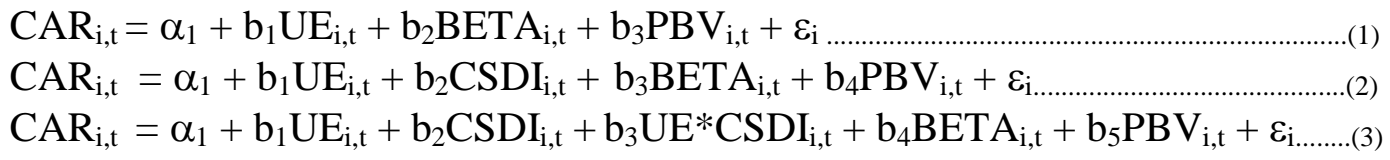

Keterangan :

$\mathrm{CAR}_{\mathrm{i}, \mathrm{t}} \quad$ : Cummulative Abnormal Return harian perusahaan i selama periode 60 hari mulai 1 April 2007 sampai 30 Juni 2007.

$\mathrm{UE}_{\mathrm{i}, \mathrm{t}} \quad$ : Unexpected Earnings perusahaan $\mathrm{i}$ yang dihitung dengan menggunakan asumsi random walk (laba sebelum pos luar biasa tahun 2006 dikurangi dengan laba sebelum pos luar biasa tahun 2005), dan diskalakan dengan harga saham perusahaan awal periode.

$\mathrm{CSDI}_{\mathrm{i}, \mathrm{t}} \quad$ : Luas pengungkapan CSR (Corporate social disclosure index) perusahaan i tahun 2006

$\mathrm{PBV}_{\mathrm{i}, \mathrm{t}} \quad$ : Price to Book Value perusahaan i tahun 2006

BETA $_{\mathrm{i}, \mathrm{t}} \quad$ : Resiko perusahaan i tahun 2006

UE*CSDI : Interaksi dari variabel UE dan CSDI

$\varepsilon_{\mathrm{i}} \quad$ : error term.

Luas pengungkapan CSR atau Corporate Social Disclosure Index (CSDI) merupakan komponen atau item-item apa saja yang diungkapkan perusahaan mengenai aktivitas CSRnya dalam annual report. Sembiring (2005) telah melakukan penyesuaian terhadap instrumen tersebut berdasarkan peraturan Bapepam No. VIII.G.2, dan menghapuskan 12 item (dari total 90 item) karena kurang sesuai untuk diterapkan di Indonesia. Total item pengungkapan CSR sebanyak 78 item tersebut juga telah disesuaikan dengan masing-masing sektor industri. Total item pengungkapan CSR adalah antara 63 sampai dengan 78, tergantung dari sektor industrinya. Checklist item pengungkapan CSR dapat dilihat pada Lampiran. Luas pengungkapan relatif sebuah perusahaan diukur dengan indeks, yaitu rasio total nilai yang diberikan kepada sebuah perusahaan dengan skor yang diharapkan dapat diperoleh perusahaan tersebut. Dari hasil perhitungan CSDI di atas, dihitung rataratanya. Luas ungkapan CSR yang di atas rata-rata akan diberi nilai 1, dan yang di bawah rata-rata diberi nilai 0 . 


\section{HASIL DAN PEMBAHASAN}

\section{Uji Asumsi Klasik}

Untuk pengujian normalitas data, dilakukan dengan melihat histogram. Dari histogram tersebut dapat dilihat bahwa penyebaran data mendekati normal sehingga pengujian lebih lanjut layak dilakukan. Hasil pengujian ini juga didukung dengan hasil normal probability plot of standardized residual yang menunjukkan bahwa titiktitik menyebar di sekitar garis diagonal dan penyebarannya mengikuti arah diagonal.

Uji multikolinearitas merupakan indikasi adanya hubungan linier diantara variabel independen. Pengujian ini dilakukan dengan menggunakan VIF (variance inflation factor). Hasil pengujian multikolinearitas menunjukkan bahwa nilai VIF di bawah 10 (paling tinggi sebesar 1,367) dan nilai toleransi yang tinggi sehingga dapat dinyatakan bahwa variabel independen bebas dari multikolinearitas.

Pengujian autokorelasi dilakukan dengan melihat nilai Durbin Watson, yaitu nilai $d w$ harus berada pada posisi antara dl dan 4-du (Gujarati, 1995). Nilai D menunjukkan nilai Durbin-Watson statistic, DU merupakan nilai batas atas tabel. Dengan $\alpha=5 \%$ maka DU $=1,571$ dan 4-DU=2,429. Nilai Durbin-Watson yang diperoleh dari pengolahan SPSS adalah sebesar 2,1203, nilai ini barada diantara 1.571 dan 2.429 sehingga dapat dinyatakan tidak terjadi autokorelasi antar variabel independen dalam model.

Heteroskedastisitas diuji dengan menggunakan metode glesjer, jika variabel independen signifikan secara statistik mempengaruhi variabel dependen, maka ada indikasi terjadi heteroskedastisitas. Hasil pengujian menunjukkan bahwa tidak ada satupun variabel independen yang signifikan secara statistik mempengaruhi varibel dependen nilai absolut. Jadi dapat disimpulkan model regresi tidak mengandung adanya heteroskesdasitas.

\section{Analisis Regresi Linear Berganda}

Hasil uji $\mathrm{F}$ menunjukkan bahwa model tersebut menunjukkan hasil yang signifikan. Nilai uji F sebesar 3.673 dengan p-value 0.004, dan tingkat signifikansi $1 \%$. Kemudian, dengan nilai $\mathrm{R}^{2}$ sebesar 0.151 dan $\mathrm{R}^{2}$ adjusted sebesar 0.110 , berarti model tersebut dapat menjelaskan variasi dari variabel dependen sebesar $11 \%$, sedangkan $89 \%$ dijelaskan oleh variabel lain.

Tabel 3. Hasil Analisis Regresi Model 3

\begin{tabular}{lrrrcc}
\hline & Koefisien & \multicolumn{1}{c}{$\mathrm{T}$} & Sig. & $\mathrm{R}^{2}$ adj & F test \\
\hline (Constant) & 6.225 & 1.967 & 0.052 & & \\
UEit & .234 & 2.256 & 0.026 & & \\
CSDI index & .041 & 0.417 & 0.678 & 0.110 & 3.673 \\
UEXCSDIindex & .094 & 0.882 & 0.380 & & $(0.004)$ \\
PBV & -.114 & -1.192 & 0.236 & & \\
BETA & -.242 & -2.587 & 0.011 & & \\
\hline
\end{tabular}


Variabel UE, dan BETA masing-masing signifikan pada level signifikansi $5 \%$. Sesuai dengan prediksi, Unexpected earning (UE) memiliki koefisien signifikan positif sebesar 0.234. Untuk variabel control, BETA memiliki koefisien signifikan negatif sebesar 2.587, Variabel PBV yang diprediksi berhubungan positif dengan CAR, hasilnya negatif sebesar 2.390 dan tidak signifikan. Variabel CSDI dan UE*CSDI dengan nilai t sebesar 0.417 dan 0.882 , tidak ada yang signifikan pada level signifikansi 5\%, dengan tingkat signifikansi masing-masing secara berturutturut 0.678 dan 0.380 , dan koefisien regresi masing-masing secara berturut-turut sebesar 0.041 dan 0.094. Dengan demikian, hipotesis 1 tidak dapat diterima pada level signifikansi 1\%, dan variabel CSDI bukan merupakan variabel moderat.

Analisis regresi dilanjutkan untuk model kedua, yaitu untuk mengidentifikasi apakah variabel CSDI merupakan variabel independen predictor. Hasil pengujian dapat dilihat pada Tabel 4 di bawah ini.

Tabel 4. Hasil Analisis Regresi Model 2

\begin{tabular}{lccccc}
\hline & Koefisien & $\mathrm{T}$ & Sig. & $\mathrm{R}^{2}$ & $\mathrm{~F}$ \\
\hline (Constant) & 6.038 & 1.914 & 0.058 & & \\
UEit & 0.277 & 3.028 & 0.003 & & \\
CSDI index & 0.027 & 0.276 & 0.783 & 0.112 & $4.406(.002)$ \\
PBV & -0.106 & -1.110 & 0.270 & & \\
BETA & -0.251 & -2.708 & 0.008 & & \\
\hline
\end{tabular}

Hasil analisis regresi untuk model kedua adalah, uji $\mathrm{F}$ menunjukkan bahwa model tersebut memberikan hasil yang signifikan. Nilai uji F sebesar 4.406 dengan p-value 0.002 , dengan tingkat signifikansi $1 \%$. Kemudian, dengan nilai $\mathrm{R}^{2}$ adjusted sebesar 0.112, berarti model tersebut dapat menjelaskan variasi dari variabel dependen sebesar $11.2 \%$, sedangkan $88.8 \%$ dijelaskan oleh variabel lain. Tabel 5 menunjukkan bahwa variabel CSDI berhubungan positif tetapi tidak signifikan terhadap variabel CAR, berarti variabel tersebut bukan merupakan variabel independen predictor. Tingkat signifikasinya jauh di atas 5\% (0.783), dan memiliki koefisien sebesar 0.027. Artinya, luas ungkapan CSR memberikan pengaruh positif untuk variabel CAR dan ERC, tetapi pengaruhnya sangat kecil. Variabel UE dan BETA signifikan pada level signifikansi $1 \%$, sedangkan variabel PBV juga tidak signifikan.

Dengan demikian, dari hasil regresi kedua model, dapat diketahui bahwa variabel CSDI bukan merupakan variabel moderat dan bukan merupakan variabel independen predictor. Dikatakan bukan variabel moderat karena variabel interaksi antara CSDI dan UE tidak signifikan pada pengujian model ke-3, dan dikatakan bukan variabel independen predictor karena pada pengujian model ke-2, variabel CSDI juga tidak signifikan. 


\section{Pengaruh Corporate Social Disclosure Index terhadap Cummulative Abnormal Return}

Tabel 3 dan tabel 4 menunjukkan bahwa variabel CSDI memberikan nilai koefisien sebesar 0.417 dengan signifikansi sebesar 0.678 (model 3) dan 0.276 (model 2) dengan signifikansi 0.783 , artinya variabel CSDI tidak berpengaruh terhadap abnormal return perusahaan. Dengan demikian, penelitian ini gagal membuktikan teori yang mengatakan bahwa luas pengungkapan CSR memiliki pengaruh terhadap kinerja pasar. Hal ini kemungkinan disebabkan karena :

1. Isu mengenai CSR merupakan hal relatif baru di Indonesia dan kebanyakan investor memiliki persepsi yang rendah terhadap hal tersebut.

2. Kualitas pengungkapan CSR tidak mudah untuk diukur, umumnya perusahaan melakukan pengungkapan CSR hanya sebagai bagian dari promosi dan menghindari untuk memberikan informasi yang relevan.

3. Kebanyakan investor di Indonesia berorientasi pada kinerja jangka pendek, sedang CSR dianggap berpengaruh pada kinerja jangka menengah dan jangka panjang.

Gupta and Goldar (2003) menemukan bahwa pasar akan memberikan 'hukuman' bagi perusahaan yang tidak peduli terhadap lingkungannya. Gozali et al (2001) membuktikan bahwa perusahaan yang lebih banyak mengungkapkan informasi sosial, akan memiliki kinerja pasar yang lebih baik dibanding perusahaan yang kurang mengungkapkan informasi tersebut. Brammer et al (2006) menemukan setiap jenis ungkapan sosial memiliki dampak yang berbeda terhadap return. Pengungkapan informasi lingkungan dan komunitas berhubungan negatif terhadap return, sedangkan informasi ketenagakerjaan berhubungan positif dengan return. Penelitian ini sama dengan penelitian Lutfi (2001, dalam Zuhroh dan Sukmawati, 2003), yang menemukan bahwa pengaruh praktek pengungkapan sosial yang dilakukan perusahaan tidak berpengaruh secara signifikan terhadap return perusahaan.

Penelitian ini belum dapat membuktikan teori mengenai manfaat pengungkapan CSR yang menyatakan bahwa kebanyakan investor akan menilai perusahaan yang bertanggung jawab secara sosial lebih aman dalam melakukan investasi. Artinya investor masih menaruh perhatian yang lebih besar pada komponen laba, dibanding pengungkapan CSR. Hasil ini sama dengan sebagian penelitian di Indonesia, yang tidak menemukan pengaruh dari pengungkapan CSR terhadap kinerja pasar modal atau reaksi investor (Lutfi, 2001; Indah, 2001; Rasmiati, 2003; dalam Dahlia dan Siregar, 2008). Sebaliknya, hasil ini bertentangan dengan lainnya dan beberapa penelitian CSR di luar negeri, yang menemukan bahwa pengungkapan sosial dan lingkungan memberikan pengaruh positif terha-dap reaksi investor dan return saham (Zuhroh dan Sukmawati, 2003; Lennox and Park, 2006; Ferraro dan Uchida, 2005; Bird et al, 2007; Gozali, 2001; Hall \& Rieck, 1998).

Banyaknya penelitian luar negeri yang menemukan adanya pengaruh positif dari pengungkapan CSR pada return saham, dan banyaknya penelitian Indonesia yang gagal membuktikan pengaruh positif tersebut, maka dapat disimpulkan bahwa 
terdapat perbedaan karakteristik investor. Investor di Indonesia masih belum mampu menggunakan pengungkapan tersebut untuk bahan pertimbangan dalam pengambilan keputusan investasi. Selain itu juga karena aktivitas CSR yang dilakukan di Indonesia masih berupa aktivitas sosial yang tidak berkelanjutan, dan dilakukan hanya untuk menjaga reputasi perusahaan.

\section{Pengaruh Corporate Social Disclosure Index (CSDI) terhadap Earning Response Coefficient (ERC)}

Hasil pengujian hipotesis 2 menunjukkan bahwa luas ungkapan CSR dalam laporan tahunan tidak meningkatkan (memperkuat) respon investor terhadap laba, atau tidak membantu investor dalam menginterpretasikan laba (H2 ditolak). Temuan ini tidak dapat membuktikan teori, yang menyebutkan bahwa pengungkapan sukarela dapat mengurangi asimetri informasi, sehingga investor dapat menginterpretasi laba dengan lebih baik. Tetapi hasil penelitian ini juga tidak bertentangan dengan teori, karena walaupun tidak signifikan luas ungkapan CSR berpengaruh positif terhadap ERC.

Teori yang digunakan dalam penelitian ini menyatakan bahwa semakin luas ungkapan dalam laporan tahunan akan mengurangi asimetri informasi, sehingga investor dapat menginterpretasi laba dengan lebih baik. Penelitian ini tidak berhasil mendukung teori tersebut. Dalam penelitian ini, pengungkapan CSR dan informasi laba bersifat komplementer (saling melengkapi). Secara rata-rata, perusahaan telah melakukan pengungkapan CSR dalam laporan tahunannya, namun ternyata luasnya pengungkapan tersebut belum dapat meningkatkan respon investor terhadap laba, artinya perusahaan yang labanya kecil walaupun melakukan banyak pengungkapan CSR, tidak akan bermanfaat atau tetap mendapat respon yang buruk. Jika dilihat dari sisi aktivitas CSR yang diungkapkan, kemungkinan aktivitas sosial yang dilakukan hanya dalam bentuk donasi dan tidak berkelanjutan; sehingga investor menganggap bahwa aktivitas tersebut tidak akan bermanfaat besar bagi kelangsungan hidup perusahaan. Alasan lain untuk menjawab hasil penelitian ini adalah bahwa laporan CSR bukan merupakan salah satu jenis ungkapan sukarela yang digunakan investor untuk mengambil keputusan. Dari penelitian sebelumnya, jenis pengungkapan sukarela yang terbukti dapat meningkatkan respon investor terhadap laba atau ERC adalah pengungkapan komponen laba yang tidak rutin, data operasional saat ini dan proyeksinya, kondisi persaingan perusahaan, strategi pemasaran, serta informasi produksi (Francis et al, 2001; Plenborg and Banghoj, 2008).

Easton dan Zmijewski, Collins dan Kothari (1989, dalam Kothari, 2001: 124) menyatakan bahwa respon pasar terhadap laba akuntansi masing-masing perusahaan dapat bervariasi, baik antar perusahaan maupun antar waktu. Hal ini menunjukkan bahwa koefisien respon laba tidak konstan. Perbedaan koefisien respon laba dipengaruhi oleh karateristik atau nilai perusahaan. Sampel penelitian ini hanya dikelompokkan berdasarkan kesensitifan perusahaan terhadap isu sosial dan lingkungan, yaitu yang termasuk kategori industri high profile. Tidak dikelompokkan lagi berdasarkan ukuran perusahaan (Size) atau tingkat perusahaan (PBV), sehingga 
hal ini juga diduga mempengaruhi hasil penelitian. Teori lain juga mengatakan ada beberapa hal yang membuat nilai ERC menjadi rendah (Beaver et al, 1980 dalam Kothari, 2001:129); pertama - prices leading earnings, informasi yang dicerminkan harga saham mengandung informasi mengenai perubahan laba dimasa mendatang, sehingga annual earnings tidak lagi tidak dapat diprediksi; kedua - Inefficient capital markets, di mana pasar gagal untuk mengapresiasi secara benar kejutan laba saat ini dalam merevisi ekspektasi future earning, maka perubahan harga akibat perubahan laba akan terlalu kecil; ketiga - Noise in earnings and deficient GAAP, kualitas laba yang rendah, sehingga akan menunjukkan hubungan yang lemah dengan return saham. Apalagi jika ditambah kondisi adanya investor irrationality (noise trading), akan memberikan kontribusi terhadap lemahnya hubungan laba dan return saham; keempat - Transitory earnings, adanya komponen laba yang tidak selalu terjadi mengakibatkan intepretasi yang berbeda.

Dilihat dari sisi penggunanya, laporan keuangan atau laporan tahunan digunakan oleh berbagai pihak yang berkepentingan, seperti investor; pemerintah; konsumen; karyawan; dan sebagainya. Karena penelitian ini menemukan bahwa pengungkapan CSR tidak dapat meningkatkan respon investor terhadap laba secara signifikan, berarti ada kemungkinan bahwa pengungkapan tersebut lebih direspon oleh pengguna yang lain. Hal ini dapat dibuktikan oleh beberapa penelitian mengenai aktivitas CSR dan dampaknya pada customer, karyawan atau calon karyawan, dan masyarakat. Brammer et al (2005) membuktikan bahwa aktivitas CSR memiliki pengaruh positif terhadap kepuasan kerja dan komitmen organisasi. Morse and Munroe (2005) menemukan bahwa customer cenderung membeli produk dari perusahaan yang bertanggung jawab pada lingkungan dan masyarakat. Bagi calon karyawan, aktivitas CSR juga memberikan daya tarik sendiri, khususnya mengenai etika, kenyaman dan keselamatan kerja Yuan et al (2008). Kemungkinan lainya, investor lebih merespon informasi laba, kemungkinan juga karena di Indonesia belum ada index CSR, seperti London Stock Exchange memiliki Socially Responsible Investment (SRI) Index, sehingga sulit bagi investor untuk membandingkan aktivitas CSR masing-masing perusahaan.

Dengan demikian dapat dikatakan bahwa ada beberapa penjelasan atas hal ini. Pertama, bisa disebabkan pihak investor yang tidak dapat menggunakan infor-masi CSR untuk menilai perusahaan; kedua, informasi CSR memang bukan hal yang perlu dipertimbangkan dalam keputusan berinvestasi karena tidak cukup memberikan informasi tentang prospek perusahaan di masa mendatang.

\section{Simpulan}

Berdasarkan hasil penelitian dan pembahasan, maka dapat disimpulkan sebagai berikut:

1. Secara simultan variabel Unexpected Earnings (UE), Corporate Social Disclosure Index (CSDI), interaksi variabel UE dan CSDI, Price to Book Value (PBV), dan Beta ditemukan berpengaruh terhadap Cummulative Abnormal Return (CAR). 
2. Dengan menggunakan Moderate Regression Analysis (MRA), Hipotesis 2 ditolak. Artinya, luas ungkapan CSR tidak memperkuat hubungan UE dan CAR. Variabel ini tidak berpengaruh secara signifikan pada Earning Response Coefficient (ERC), hal ini sesuai dengan teori yang ada dapat meningkatkan respon terhadap laba.

3. Secara parsial variabel CSDI tidak signifikan berpengaruh terhadap Cummulative Abnormal Return (CAR) dengan koefisien determinasi par-sial sebesar 0.417. Secara parsial variabel UE berpengaruh secara signifikan terhadap Cummulative Abnormal Return (CAR) dengan koefisien determinasi parsial sebesar 2.256, Hipotesis 1 diterima. Variabel Beta juga berpengaruh secara signifikan terhadap Cummulative Abnormal Return (CAR) dengan koefisien determinasi parsial sebesar -2.587, Hipotesis 3 diterima. Variabel PBV secara parsial tidak berpengaruh secara signifikan terhadap Cummulative Abnormal Return (CAR) dengan koefisien deter-minasi parsial sebesar -1.192, Hipotesis 4 ditolak.

\section{Keterbatasan dan Saran}

Adapun keterbatasan dan saran yang dapat dikemukakan adalah:

1. Penelitian ini hanya menggunakan periode satu tahun dan tidak diambil tahun yang paling mutakhir, yaitu tahun 2006 karena setelah tahun 2006, pengungkapan CSR menjadi mandatory disclosure. Diharapkan penelitian selanjutnya dapat memperpanjang periode penelitian dan menggunakan tahun terbaru.

2. Pengukuran ERC dilakukan secara cross-section, penelitian selanjutnya dapat mengukur ERC dari beberapa periode waktu. Dengan melakukan pengukuran yang berbeda, mungkin akan memperoleh hasil yang berbeda.

3. Penelitian ini telah membedakan jenis industri berdasarkan kesensitifannya terhadap issue sosial (high profile dan low profile), tetapi belum membedakan jenis ungkapan CSR yang dilakukan perusahaan, misalnya pengungkapan aktivitas lingkungan dan pengungkapan aktivitas sosial lebih direspon yang mana. Penelitian selanjutnya juga dapat menguji perbedaan pengaruh pengungkapan CSR pada masing-masing industri, atau membandingkan antar industri, misalnya perbankan dengan non perbankan 


\section{DAFTAR PUSTAKA}

Adhariani, Desy. 2005. "Tingkat Keluasan Pengungkapan Sukarela Dalam Laporan Tahunan dan Hubungannya dengan Earning Response Coefficient (ERC)". Jurnal Akuntansi dan Keuangan Indonesia, Vol.2, No.1, July, p.24 - 57.

Bangh $\varnothing \mathrm{j}$, Jesper, Thomas Plenborg. 2008. "Value Relevance of Voluntary Disclosure in the Annual Report". Accounting and Finance, 48 (2008) 159-180.

Beaver, William H., 1968. "The Information Content of Annual Earnings Announcements". Journal of Accounting Research, p. 67-92.

Bird, et al. 2007. "What Corporate Social Responsibility Activities are Valued by The Market?". Journal of Business Ethics, p.189 - 206

Brammer et al. 2005. The contribution of Corporate Social Responsibility to organizational commitment. Working paper series.

Dahlia, L., Sylvis V.S. 2008. "Pengaruh CSR Terhadap Kinerja Perusahaan". Simposium Nasional Akuntansi XI, Pontianak.

Ferraro, Paul J., dan Toshihiro Uchida. 2005. "Investor reactions to information disclosure : Can provide public information about firms pollution improve environmental performance?". Water policy working paper.

Financial Accounting Standards Board. 1978. Statement Of Financial Accounting Concepts. High Ridge Park. Stamford.

Francis, J., Katherine S., Linda V. 2002. " Expanded Disclosure and The Increased Usefulness of Earnings Announcements". The Accounting Review, july, p.515 546.

Gelb, D., and P. Zarowin. 2000. "Corporate Disclosure Policy and The Informativeness of Stock Prices". Working Paper, Seton Hall University and New York University.

Ghozali, Imam. 2007. Aplikasi Analisis Multivariate dengan program SPSS. Cetakan IV. Badan Penerbit Undip. Semarang.

Gozali et al. 2001. The Economic Consequences of Voluntary Environmental Information Disclosure. Australia.

Gupta S., and Goldar B. 2003. Do Stock Markets Penalise Environment - Unfriendly Behaviour? Evidence from India.

Hackston, D., and M.J. Milne. 1996. "Some determinants of social and environmental disclosures in New Zealand companies". Accounting, Auditing \& Accountability Journal 9, no.1 : 77-108.

Hall, P.L., dan Robin R. 1998. "The effect of positive corporate social actions on shareholder wealth. Journal of financial and strategic decisions, Vol. 11 No. 2, pp 83-89.

Kiroyan, Noke. 2006. "Good Corporate Governance (GCG) dan Corporate Social Responsibility (CSR) Adakah Kaitan di Antara Keduanya?". Economicss Business Accounting Review, Edisi III, September-Desember 2006. Hal 45-58.

Kothari, S.P. 2001. Capital Market Research In Accounting. Journal Of Accounting and Economics, 31, p.105-231. 
Lang, Mark dan R. Lundholm. 1993. "Corporate disclosure policy and analyst behavior". The accounting review, Vol. 71, No.4, Oktober, 467-492.

Lennox, Clive S dan Chul W.Park. 2006. "The informativeness of earnings ang management's issuance of earnings forecasts". Journal of Accounting and Economics, p.439-458.

Myburgh, JE. 2001. "The informativeness of voluntarydisclosure in the annual reports of listed industrial companies in South Africa". Meditari Accountancy Research Vol. 9 2001: 199-216.

Riduwan, Akhmad. 2004. "Pengaruh Alokasi Pajak Antar Perioda Berdasarkan PSAK No. 46 Terhadap Koefisien Respon Laba Akuntansi. Simposium Nasional Akuntansi VII, Bali 2-3 Desember 2004.

Sayekti, Yosefa dan L. Sensi Wondabio. 2007. "Pengaruh CSR disclosure terhadap earning response coefficient”. Simposium Nasional Akuntansi X, Semarang 2628 Juli 2007.

Scott, William r. 2006. Financial Accounting Theory. Fourth edition. Canada. Pearson, Prentice Hall.

Sembiring, Eddy Rismanda. 2005. Karakteristik perusahaan dan pengungkapan tanggung jawab sosial : studi empiris pada perusahaan yang tercatat di bursa efek jakarta. Simposium Nasional Akuntansi VIII. 15-16 September 2005, Solo.

Suaryana, Agung. 2005. "Pengaruh Komite Audit Terhadap Kualitas Laba". Simposium Nasional Akuntansi VIII, Solo 15-16 September 2003.

Sudarno, 2005. "Hubungan size dan profitabilitas perusahaan dengan pengungkapam informasi lingkungan dan perbedaan pengungkapan berdasarkan tipe industri". Thesis, Universitas Airlangga, Surabaya.

Widiastuti, Harjanti. 2002. "Pengaruh luas pengungkapan sukarela dalam laporan tahunan terhadap earning response coefficient (ERC)". Simposium Nasional Akuntansi V, Semarang 5-6 September 2002.

Yuan et al. 2008. The role of corporate social responsibility (CSR) in job choice decisions in the greater china region. EU-CHINA BMT Conference Papers and Proceedings.

Zuhroh, Diana, dan I Putu Pande H. Sukmawati. 2003. “Analisis pengaruh luas pengungkapan sosial dalam laporan tahunan perusahaan terhadap reaksi investor”. Simposium Nasional Akuntansi VI, 2003. 


\section{Lampiran 1}

Item-Item Pengungkapan Tanggung Jawab Sosial Perusahaan

\begin{tabular}{|c|c|c|c|c|c|c|c|c|c|c|c|c|c|}
\hline \multirow{2}{*}{\multicolumn{2}{|c|}{ KATEGORI }} & \multicolumn{12}{|c|}{ Sektor Industri } \\
\hline & & 1 & 2 & 3 & 4 & 5 & 6 & 7 & 8 & 9 & 10 & 11 & 12 \\
\hline \multicolumn{14}{|c|}{ Lingkungan } \\
\hline 1 & $\begin{array}{l}\text { Pengendalian polusi kegiatan operasi; } \\
\text { pengeluaran riset dan pengembangan untuk } \\
\text { pengurangan polusi }\end{array}$ & $\mathrm{Y}$ & $\mathrm{Y}$ & $\mathrm{Y}$ & $\mathrm{Y}$ & $\mathrm{Y}$ & $\mathrm{Y}$ & $\mathrm{T}$ & $\mathrm{T}$ & $\mathrm{T}$ & $\mathrm{T}$ & $\mathrm{Y}$ & $\mathrm{Y}$ \\
\hline 2 & $\begin{array}{l}\text { Pernyataan yang menunjukkan bahwa operasi } \\
\text { perusahaan tidak mengakibatkan polusi atau } \\
\text { memenuhi ketentuan hukum dan peraturan } \\
\text { polusi; }\end{array}$ & $\mathrm{Y}$ & $\mathrm{Y}$ & $\mathrm{Y}$ & $\mathrm{Y}$ & $\mathrm{Y}$ & $\mathrm{Y}$ & $\mathrm{Y}$ & Y & $\mathrm{Y}$ & $\mathrm{Y}$ & $\mathrm{Y}$ & $\mathrm{Y}$ \\
\hline 3 & $\begin{array}{l}\text { Pernyataan yang menunjukkan bahwa polusi } \\
\text { operasi telah atau akan dikurangi; }\end{array}$ & $\mathrm{Y}$ & $\mathrm{Y}$ & $\mathrm{Y}$ & $\mathrm{Y}$ & $\mathrm{Y}$ & $\mathrm{Y}$ & $\mathrm{T}$ & $\mathrm{T}$ & $\mathrm{T}$ & $\mathrm{T}$ & $\mathrm{Y}$ & $\mathrm{Y}$ \\
\hline 4 & $\begin{array}{l}\text { Pencegahan atau perbaikan kerusakan } \\
\text { lingkungan akibat pengolahan sumber alam, } \\
\text { misalnya reklamasi daratan atau reboisasi; }\end{array}$ & $\mathrm{Y}$ & $\mathrm{T}$ & $\mathrm{Y}$ & $\mathrm{T}$ & $\mathrm{Y}$ & $\mathrm{T}$ & $\mathrm{T}$ & $\mathrm{T}$ & $\mathrm{T}$ & $\mathrm{T}$ & $\mathrm{Y}$ & $\mathrm{Y}$ \\
\hline 5 & $\begin{array}{l}\text { Konservasi sumber alam, misalnya mendaur } \\
\text { ulang kaca, besi, minyak, air dan kertas; }\end{array}$ & $\mathrm{T}$ & $\mathrm{T}$ & $\mathrm{Y}$ & $\mathrm{T}$ & $\mathrm{Y}$ & $\mathrm{T}$ & $\mathrm{T}$ & $\mathrm{T}$ & $\mathrm{T}$ & $\mathrm{T}$ & $\mathrm{Y}$ & $\mathrm{Y}$ \\
\hline 6 & Penggunaan material daur ulang; & $\mathrm{T}$ & $\mathrm{T}$ & $\mathrm{Y}$ & $\mathrm{Y}$ & $\mathrm{Y}$ & $\mathrm{Y}$ & $\mathrm{T}$ & $\mathrm{T}$ & $\mathrm{T}$ & $\mathrm{T}$ & $\mathrm{Y}$ & $\mathrm{Y}$ \\
\hline 7 & $\begin{array}{l}\text { Menerima penghargaan berkaitan dengan } \\
\text { program lingkungan yang dibuat perusahaan; }\end{array}$ & $\mathrm{Y}$ & $\mathrm{Y}$ & $\mathrm{Y}$ & $\mathrm{Y}$ & $\mathrm{Y}$ & Y & $\mathrm{Y}$ & $\mathrm{Y}$ & Y & Y & $\mathrm{Y}$ & $\mathrm{Y}$ \\
\hline 8 & $\begin{array}{l}\text { Merancang fasilitas yang harmonis dengan } \\
\text { lingkungan; }\end{array}$ & $\mathrm{Y}$ & $\mathrm{Y}$ & $\mathrm{Y}$ & $\mathrm{Y}$ & $\mathrm{Y}$ & $\mathrm{Y}$ & $\mathrm{Y}$ & $\mathrm{Y}$ & $\mathrm{Y}$ & $\mathrm{Y}$ & $\mathrm{Y}$ & $\mathrm{Y}$ \\
\hline 9 & $\begin{array}{l}\text { Kontribusi dalam seni yang bertujuan untuk } \\
\text { memperindah lingkungan }\end{array}$ & $\mathrm{Y}$ & $\mathrm{Y}$ & $\mathrm{Y}$ & $\mathrm{Y}$ & $\mathrm{Y}$ & $\mathrm{Y}$ & $\mathrm{Y}$ & $\mathrm{Y}$ & $\mathrm{Y}$ & $\mathrm{Y}$ & $\mathrm{Y}$ & $\mathrm{Y}$ \\
\hline 10 & $\begin{array}{l}\text { Kontribusi dalam pemugaran bangunan } \\
\text { sejarah }\end{array}$ & $\mathrm{Y}$ & $\mathrm{Y}$ & $\mathrm{Y}$ & $\mathrm{Y}$ & $\mathrm{Y}$ & $\mathrm{Y}$ & $\mathrm{Y}$ & $\mathrm{Y}$ & $\mathrm{Y}$ & $\mathrm{Y}$ & $\mathrm{Y}$ & $\mathrm{Y}$ \\
\hline 11 & Pengolahan limbah & $\mathrm{Y}$ & $\mathrm{Y}$ & $\mathrm{Y}$ & $\mathrm{T}$ & $\mathrm{Y}$ & $\mathrm{T}$ & $\mathrm{T}$ & $\mathrm{T}$ & $\mathrm{T}$ & $\mathrm{T}$ & $\mathrm{Y}$ & $\mathrm{Y}$ \\
\hline 12 & $\begin{array}{l}\text { Mempelajari dampak lingkungan untuk } \\
\text { memonitor dampak lingkungan perusahaan; }\end{array}$ & $\mathrm{Y}$ & $\mathrm{Y}$ & $\mathrm{Y}$ & $\mathrm{Y}$ & $\mathrm{Y}$ & $\mathrm{Y}$ & $\mathrm{T}$ & $\mathrm{Y}$ & $\mathrm{T}$ & $\mathrm{T}$ & $\mathrm{Y}$ & $\mathrm{Y}$ \\
\hline 13 & Perlindungan lingkungan hidup. & $\mathrm{Y}$ & $\mathrm{Y}$ & $\mathrm{Y}$ & $\mathrm{Y}$ & $\mathrm{Y}$ & $\mathrm{Y}$ & $\mathrm{Y}$ & $\mathrm{Y}$ & $\mathrm{Y}$ & $\mathrm{Y}$ & $\mathrm{Y}$ & $\mathrm{Y}$ \\
\hline \multicolumn{14}{|c|}{ Energy } \\
\hline 1 & $\begin{array}{l}\text { Menggunakan energi secara lebih efisien } \\
\text { dalam kegiatan operasi; }\end{array}$ & $\mathrm{Y}$ & $\mathrm{Y}$ & $\mathrm{Y}$ & $\mathrm{Y}$ & $\mathrm{Y}$ & $\mathrm{Y}$ & $\mathrm{Y}$ & $\mathrm{Y}$ & $Y$ & $\mathrm{Y}$ & $\mathrm{Y}$ & $\mathrm{Y}$ \\
\hline 2 & $\begin{array}{l}\text { Memanfaatkan barang bekas untuk } \\
\text { memproduksi energi; }\end{array}$ & $\mathrm{T}$ & $\mathrm{Y}$ & $\mathrm{Y}$ & $\mathrm{T}$ & $\mathrm{Y}$ & $\mathrm{T}$ & $\mathrm{T}$ & $\mathrm{T}$ & $\mathrm{T}$ & $\mathrm{T}$ & $\mathrm{Y}$ & $Y$ \\
\hline 3 & $\begin{array}{l}\text { Mengungkapkan penghematan energi sebagai } \\
\text { hasil produk daur ulang; }\end{array}$ & $\mathrm{T}$ & $\mathrm{Y}$ & $\mathrm{Y}$ & $\mathrm{T}$ & $\mathrm{Y}$ & $\mathrm{T}$ & $\mathrm{T}$ & $\mathrm{T}$ & $\mathrm{T}$ & $\mathrm{T}$ & $\mathrm{Y}$ & $\mathrm{Y}$ \\
\hline 4 & $\begin{array}{l}\text { Membahas upaya perusahaan dalam } \\
\text { mengurangi konsumsi energi; }\end{array}$ & $\mathrm{Y}$ & $\mathrm{Y}$ & $\mathrm{Y}$ & $\mathrm{Y}$ & $\mathrm{Y}$ & $\mathrm{Y}$ & $\mathrm{Y}$ & $\mathrm{Y}$ & $\mathrm{Y}$ & $\mathrm{Y}$ & $\mathrm{Y}$ & $\mathrm{Y}$ \\
\hline 5 & $\begin{array}{l}\text { Pengungkapan peningkatan efisiensi energi } \\
\text { dari produk }\end{array}$ & $\mathrm{T}$ & $\mathrm{T}$ & $\mathrm{Y}$ & $\mathrm{T}$ & $\mathrm{Y}$ & $\mathrm{Y}$ & $\mathrm{T}$ & $\mathrm{T}$ & $\mathrm{T}$ & $\mathrm{T}$ & $\mathrm{Y}$ & $\mathrm{Y}$ \\
\hline 6 & $\begin{array}{l}\text { Riset yang mengarah pada peningkatan } \\
\text { efisiensi energi dari produk; }\end{array}$ & $\mathrm{Y}$ & $\mathrm{T}$ & $\mathrm{Y}$ & $\mathrm{T}$ & $\mathrm{Y}$ & $\mathrm{Y}$ & $\mathrm{T}$ & $\mathrm{T}$ & $\mathrm{T}$ & $\mathrm{T}$ & $\mathrm{Y}$ & $\mathrm{Y}$ \\
\hline 7 & Mengungkapkan kebijakan energi & $\mathrm{Y}$ & $\mathrm{Y}$ & $\mathrm{Y}$ & $\mathrm{Y}$ & $\mathrm{Y}$ & $\mathrm{Y}$ & $\mathrm{Y}$ & $\mathrm{Y}$ & $\mathrm{Y}$ & $\mathrm{Y}$ & $\mathrm{Y}$ & $\mathrm{Y}$ \\
\hline
\end{tabular}




\begin{tabular}{|c|c|c|c|c|c|c|c|c|c|c|c|c|c|}
\hline & perusantadin. & & & & & & & & & & & & \\
\hline \multicolumn{14}{|c|}{ Kesehatan Dan Keselamatan Tenaga kerja } \\
\hline 1 & $\begin{array}{l}\text { Mengurangi polusi, iritasi, atau resiko dalam } \\
\text { lingkungan kerja; }\end{array}$ & $\mathrm{Y}$ & $\mathrm{Y}$ & $\mathrm{Y}$ & $\mathrm{Y}$ & $\mathrm{Y}$ & $\mathrm{Y}$ & $\mathrm{Y}$ & $\mathrm{Y}$ & $\mathrm{Y}$ & Y & $\mathrm{Y}$ & $\mathrm{Y}$ \\
\hline 2 & $\begin{array}{l}\text { Mempromosikan keselamatan tenaga kerja } \\
\text { dan kesehatan fisik atau mental; }\end{array}$ & $\mathrm{Y}$ & $\mathrm{Y}$ & Y & Y & $\mathrm{Y}$ & $\mathrm{Y}$ & $\mathrm{Y}$ & $\mathrm{Y}$ & Y & $\mathrm{Y}$ & $\mathrm{Y}$ & $\mathrm{Y}$ \\
\hline 3 & Mengungkapkan statistik kecelakaan kerja; & $\mathrm{Y}$ & $\mathrm{Y}$ & $\mathrm{Y}$ & $\mathrm{Y}$ & $\mathrm{Y}$ & $\mathrm{Y}$ & $\mathrm{Y}$ & $\mathrm{Y}$ & $\mathrm{Y}$ & $\mathrm{Y}$ & $\mathrm{Y}$ & $\mathrm{Y}$ \\
\hline 4 & $\begin{array}{l}\text { Mentaati peraturan standard kesehatan dan } \\
\text { keselamatan kerja }\end{array}$ & $\mathrm{Y}$ & $\mathrm{Y}$ & Y & $\mathrm{Y}$ & $\mathrm{Y}$ & $\mathrm{Y}$ & $\mathrm{Y}$ & Y & $\mathrm{Y}$ & Y & $\mathrm{Y}$ & $\mathrm{Y}$ \\
\hline 5 & $\begin{array}{l}\text { Menerima penghargaan berkaitan dengan } \\
\text { keselamatan kerja; }\end{array}$ & $\mathrm{Y}$ & $\mathrm{Y}$ & Y & $\mathrm{Y}$ & $\mathrm{Y}$ & $\mathrm{Y}$ & $\mathrm{Y}$ & Y & Y & $\mathrm{Y}$ & $\mathrm{Y}$ & $\mathrm{Y}$ \\
\hline 6 & Menetapkan suatu komite keselamatan kerja & $\mathrm{Y}$ & $\mathrm{Y}$ & $\mathrm{Y}$ & $\mathrm{Y}$ & $\mathrm{Y}$ & $\mathrm{Y}$ & $\mathrm{Y}$ & $\mathrm{Y}$ & $\mathrm{Y}$ & $\mathrm{Y}$ & $\mathrm{Y}$ & $\mathrm{Y}$ \\
\hline 7 & $\begin{array}{l}\text { Melaksanakan riset untuk meningkatkan } \\
\text { keselamatan kerja; }\end{array}$ & $\mathrm{Y}$ & $\mathrm{Y}$ & $\mathrm{Y}$ & $\mathrm{Y}$ & $\mathrm{Y}$ & $\mathrm{Y}$ & $\mathrm{Y}$ & $\mathrm{Y}$ & $\mathrm{Y}$ & $\mathrm{Y}$ & $\mathrm{Y}$ & $\mathrm{Y}$ \\
\hline 8 & $\begin{array}{l}\text { Mengungkapkan pelayanan kesehatan tenaga } \\
\text { kerja }\end{array}$ & $\mathrm{Y}$ & $\mathrm{Y}$ & $\mathrm{Y}$ & $\mathrm{Y}$ & $\mathrm{Y}$ & $\mathrm{Y}$ & $\mathrm{Y}$ & $\mathrm{Y}$ & $\mathrm{Y}$ & $\mathrm{Y}$ & $\mathrm{Y}$ & $\mathrm{Y}$ \\
\hline \multicolumn{14}{|c|}{ Lain-lain tentang Tenaga kerja } \\
\hline 1 & $\begin{array}{l}\text { Perekrutan atau memanfaatkan tenaga kerja } \\
\text { wanita/orang cacat }\end{array}$ & $\mathrm{Y}$ & $\mathrm{Y}$ & Y & Y & $\mathrm{Y}$ & $\mathrm{Y}$ & $\mathrm{Y}$ & $\mathrm{Y}$ & $\mathrm{Y}$ & $\mathrm{Y}$ & $\mathrm{Y}$ & $\mathrm{Y}$ \\
\hline 2 & $\begin{array}{l}\text { Mengungkapkan persentase/jumlah tenaga } \\
\text { kerja wanita/orang cacat dalam tingkat } \\
\text { managerial; }\end{array}$ & $\mathrm{Y}$ & $\mathrm{Y}$ & $\mathrm{Y}$ & $\mathrm{Y}$ & $\mathrm{Y}$ & $\mathrm{Y}$ & $\mathrm{Y}$ & $\mathrm{Y}$ & $\mathrm{Y}$ & $\mathrm{Y}$ & $\mathrm{Y}$ & $\mathrm{Y}$ \\
\hline 3 & $\begin{array}{l}\text { Mengungkapkan tujuan penggunaan tenaga } \\
\text { kerja wanita/orang cacat dalam pekerjaan }\end{array}$ & $\mathrm{Y}$ & $\mathrm{Y}$ & Y & $\mathrm{Y}$ & $\mathrm{Y}$ & $\mathrm{Y}$ & $\mathrm{Y}$ & $\mathrm{Y}$ & $\mathrm{Y}$ & $\mathrm{Y}$ & $\mathrm{Y}$ & $\mathrm{Y}$ \\
\hline 4 & $\begin{array}{l}\text { Program untuk kemajuan tenaga kerja } \\
\text { wanita/orang cacat }\end{array}$ & $\mathrm{Y}$ & $\mathrm{Y}$ & Y & $\mathrm{Y}$ & $\mathrm{Y}$ & $\mathrm{Y}$ & $\mathrm{Y}$ & Y & $\mathrm{Y}$ & $\mathrm{Y}$ & $\mathrm{Y}$ & Y \\
\hline 5 & $\begin{array}{l}\text { a kerja melalui program } \\
\text { bat kerja }\end{array}$ & $\mathrm{Y}$ & $\mathrm{Y}$ & $\mathrm{Y}$ & $\mathrm{Y}$ & $\mathrm{Y}$ & $\mathrm{Y}$ & $\mathrm{Y}$ & $\mathrm{Y}$ & $\mathrm{Y}$ & $\mathrm{Y}$ & $\mathrm{Y}$ & $\mathrm{Y}$ \\
\hline 6 & $\begin{array}{l}\text { Memberi bantuan keuangan pada tenaga kerja } \\
\text { dalam bidang pendidikan }\end{array}$ & $\mathrm{Y}$ & $\mathrm{Y}$ & $\mathrm{Y}$ & $\mathrm{Y}$ & $\mathrm{Y}$ & $\mathrm{Y}$ & $\mathrm{Y}$ & $\mathrm{Y}$ & $\mathrm{Y}$ & $\mathrm{Y}$ & $\mathrm{Y}$ & $\mathrm{Y}$ \\
\hline 7 & $\begin{array}{l}\text { Mendirikan suatu pusat pelatihan tenaga } \\
\text { kerja. }\end{array}$ & $\mathrm{Y}$ & $\mathrm{Y}$ & 1 & 1 & 1 & 1 & $\mathbf{r}$ & Y & Y & 1 & 1 & $\mathrm{Y}$ \\
\hline 8 & $\begin{array}{l}\text { Mengungkapkan bantuan atau bimbingan } \\
\text { untuk tenaga kerja yang dalam proses } \\
\text { mengundurkan diri atau yang telah membuat } \\
\text { kesalahan }\end{array}$ & $\mathrm{Y}$ & $\mathrm{Y}$ & $\mathrm{Y}$ & $\mathrm{Y}$ & $\mathrm{Y}$ & $\mathrm{Y}$ & $\mathrm{Y}$ & $\mathrm{Y}$ & $\mathrm{Y}$ & $\mathrm{Y}$ & $\mathrm{Y}$ & $\mathrm{Y}$ \\
\hline 9 & $\begin{array}{l}\text { Mengungkapkan perencanaan kepemilikan } \\
\text { rumah karyawan; }\end{array}$ & $\mathrm{Y}$ & $\mathrm{Y}$ & $\mathrm{Y}$ & $\mathrm{Y}$ & $\mathrm{Y}$ & $\mathrm{Y}$ & $\mathrm{Y}$ & $Y$ & $\mathrm{Y}$ & $\mathrm{Y}$ & $\mathrm{Y}$ & $\mathrm{Y}$ \\
\hline 10 & $\begin{array}{l}\text { Mengungkapkan fasilitas untuk aktivitas } \\
\text { rekreasi }\end{array}$ & $\mathrm{Y}$ & Y & $Y$ & Y & $\mathrm{Y}$ & $\mathrm{Y}$ & $\mathrm{Y}$ & Y & Y & $\mathrm{Y}$ & $\mathrm{Y}$ & $\mathrm{Y}$ \\
\hline 11 & $\begin{array}{l}\text { Pengungkapkan persentase gaji untuk } \\
\text { pensiun; }\end{array}$ & $\mathrm{Y}$ & Y & $Y$ & $Y$ & $\mathrm{Y}$ & $\mathrm{Y}$ & Y & Y & $\mathrm{Y}$ & $\mathrm{Y}$ & $Y$ & $\mathrm{Y}$ \\
\hline 12 & $\begin{array}{l}\text { Mengungkapkan kebijakan penggajian dalam } \\
\text { perusahaan }\end{array}$ & $\mathrm{Y}$ & $\mathrm{Y}$ & $\mathrm{Y}$ & $\mathrm{Y}$ & $\mathrm{Y}$ & $\mathrm{Y}$ & $\mathrm{Y}$ & $Y$ & $\mathrm{Y}$ & $\mathrm{Y}$ & $\mathrm{Y}$ & $\mathrm{Y}$ \\
\hline 13 & $\begin{array}{l}\text { Mengungkapkan jumlah tenaga kerja dalam } \\
\text { perusahaan }\end{array}$ & $\mathrm{Y}$ & $\mathrm{Y}$ & $\mathrm{Y}$ & $\mathrm{Y}$ & $\mathrm{Y}$ & $\mathrm{Y}$ & $\mathrm{Y}$ & $\mathrm{Y}$ & $\mathrm{Y}$ & $\mathrm{Y}$ & $\mathrm{Y}$ & $\mathrm{Y}$ \\
\hline 14 & $\begin{array}{l}\text { Mengungkapkan tingkatan managerial yang } \\
\text { ada }\end{array}$ & $\mathrm{Y}$ & $\mathrm{Y}$ & $Y$ & $Y$ & $\mathbf{Y}$ & $\mathrm{Y}$ & $\mathrm{Y}$ & $Y$ & 1 & $Y$ & $\mathrm{Y}$ & $\mathrm{Y}$ \\
\hline 15 & Mengungkapkan disposisi staff - di mana & $\mathrm{Y}$ & $\mathrm{Y}$ & $\mathrm{Y}$ & $\mathrm{Y}$ & $\mathrm{Y}$ & $\mathrm{Y}$ & $\mathrm{Y}$ & $\mathrm{Y}$ & $\mathrm{Y}$ & $\mathrm{Y}$ & $\mathrm{Y}$ & $\mathrm{Y}$ \\
\hline
\end{tabular}




\begin{tabular}{|c|c|c|c|c|c|c|c|c|c|c|c|c|c|}
\hline & staff ditempatkan & & & & & & & & & & & & \\
\hline 16 & $\begin{array}{l}\text { Mengungkapkan jumlah staff, masa kerja dan } \\
\text { kelompok usia mereka; }\end{array}$ & $\mathrm{Y}$ & $\mathrm{Y}$ & $\mathrm{Y}$ & $\mathrm{Y}$ & $\mathrm{Y}$ & $\mathrm{Y}$ & $\mathrm{Y}$ & $\mathrm{Y}$ & $\mathrm{Y}$ & $\mathrm{Y}$ & $\mathrm{Y}$ & $\mathrm{Y}$ \\
\hline 17 & $\begin{array}{l}\text { Mengungkapkan statistik tenaga kerja, mis. } \\
\text { penjualan per tenaga kerja; }\end{array}$ & $\mathrm{Y}$ & $\mathrm{Y}$ & $\mathrm{Y}$ & $\mathrm{Y}$ & $\mathrm{Y}$ & $\mathrm{Y}$ & $\mathrm{Y}$ & $\mathrm{Y}$ & $\mathrm{Y}$ & $\mathrm{Y}$ & $\mathrm{Y}$ & $\mathrm{Y}$ \\
\hline 18 & $\begin{array}{l}\text { Mengungkapkan kualifikasi tenaga kerja yang } \\
\text { direkrut. }\end{array}$ & $\mathrm{Y}$ & $\mathrm{Y}$ & $\mathrm{Y}$ & $\mathrm{Y}$ & $\mathrm{Y}$ & $\mathrm{Y}$ & Y & $\mathrm{Y}$ & $\mathrm{Y}$ & $\mathrm{Y}$ & Y & $\mathrm{Y}$ \\
\hline 19 & $\begin{array}{l}\text { Mengungkapkan rencana kepemilikan saham } \\
\text { oleh tenaga kerja; }\end{array}$ & $\mathrm{Y}$ & $\mathrm{Y}$ & Y & $\mathrm{Y}$ & $\mathrm{Y}$ & $\mathrm{Y}$ & $\mathrm{Y}$ & $\mathrm{Y}$ & $\mathrm{Y}$ & $\mathrm{Y}$ & $\mathrm{Y}$ & $\mathrm{Y}$ \\
\hline 20 & $\begin{array}{l}\text { Mengungkapkan rencana pembagian } \\
\text { keuntungan lain. }\end{array}$ & $\mathrm{Y}$ & $\mathrm{Y}$ & Y & $\mathrm{Y}$ & $\mathrm{Y}$ & $\mathrm{Y}$ & Y & $\mathrm{Y}$ & $\mathrm{Y}$ & $\mathrm{Y}$ & Y & $\mathrm{Y}$ \\
\hline 21 & $\begin{array}{l}\text { Mengungkapkan informasi hubungan } \\
\text { manajemen dengan tenaga kerja dalam } \\
\text { meningkatkan kepuasan dan motivasi kerja; }\end{array}$ & $\mathrm{Y}$ & $\mathrm{Y}$ & $\mathrm{Y}$ & $\mathrm{Y}$ & $\mathrm{Y}$ & $\mathrm{Y}$ & Y & $\mathrm{Y}$ & $\mathrm{Y}$ & $\mathrm{Y}$ & $\mathrm{Y}$ & $\mathrm{Y}$ \\
\hline 22 & $\begin{array}{l}\text { Mengungkapkan informasi stabilitas } \\
\text { pekerjaan tenaga kerja dan masa depan } \\
\text { perusahaan; }\end{array}$ & $\mathrm{Y}$ & $\mathrm{Y}$ & $\mathrm{Y}$ & $\mathrm{Y}$ & $\mathrm{Y}$ & $\mathrm{Y}$ & $\mathrm{Y}$ & $\mathrm{Y}$ & $\mathrm{Y}$ & $\mathrm{Y}$ & $\mathrm{Y}$ & $\mathrm{Y}$ \\
\hline 23 & Membuat laporan tenaga kerja yang terpisah; & $\mathrm{Y}$ & $\mathrm{Y}$ & $\mathrm{Y}$ & $\mathrm{Y}$ & $\mathrm{Y}$ & $\mathrm{Y}$ & $\mathrm{Y}$ & $\mathrm{Y}$ & $\mathrm{Y}$ & $\mathrm{Y}$ & $\mathrm{Y}$ & $\mathrm{Y}$ \\
\hline 24 & $\begin{array}{l}\text { Melaporkan hubungan perusahaan dengan } \\
\text { serikat buruh }\end{array}$ & $\mathrm{Y}$ & $Y$ & Y & $\mathrm{Y}$ & $\mathrm{Y}$ & $\mathrm{Y}$ & $\mathrm{Y}$ & $\mathrm{Y}$ & $\mathrm{Y}$ & $\mathrm{Y}$ & Y & $\mathrm{Y}$ \\
\hline 25 & Melaporkan gangguan dan aksi tenaga kerja & $\mathrm{Y}$ & $\mathrm{Y}$ & $\mathrm{Y}$ & $\mathrm{Y}$ & $\mathrm{Y}$ & $\mathrm{Y}$ & $\mathrm{Y}$ & $\mathrm{Y}$ & $\mathrm{Y}$ & $\mathrm{Y}$ & $\mathrm{Y}$ & $\mathrm{Y}$ \\
\hline 26 & $\begin{array}{l}\text { Mengungkapkan informasi bagaimana aksi } \\
\text { tenaga kerja dinegosiasikan. }\end{array}$ & $\mathrm{Y}$ & $\mathrm{Y}$ & $\mathrm{Y}$ & $\mathrm{Y}$ & $\mathrm{Y}$ & $\mathrm{Y}$ & $\mathrm{Y}$ & $\mathrm{Y}$ & Y & $\mathrm{Y}$ & $\mathrm{Y}$ & $\mathrm{Y}$ \\
\hline 27 & Peningkatan kondisi kerja secara umum; & $\mathrm{Y}$ & $\mathrm{Y}$ & $\mathrm{Y}$ & $\mathrm{Y}$ & $\mathrm{Y}$ & $\mathrm{Y}$ & $\mathrm{Y}$ & $\mathrm{Y}$ & $\mathrm{Y}$ & $\mathrm{Y}$ & $\mathrm{Y}$ & $\mathrm{Y}$ \\
\hline 28 & $\begin{array}{l}\text { Informasi re-organisasi perusahaan yang } \\
\text { mempengaruhi tenaga kerja; }\end{array}$ & $\mathrm{Y}$ & $\mathrm{Y}$ & $\mathrm{Y}$ & Y & $\mathrm{Y}$ & $\mathrm{Y}$ & Y & $\mathrm{Y}$ & $\mathrm{Y}$ & $\mathrm{Y}$ & $\mathrm{Y}$ & $\mathrm{Y}$ \\
\hline 29 & $\begin{array}{l}\text { Informasi dan statistik perputaran tenaga } \\
\text { kerja }\end{array}$ & $\mathrm{Y}$ & $\mathrm{Y}$ & $\mathrm{Y}$ & $\mathrm{Y}$ & $\mathrm{Y}$ & $\mathrm{Y}$ & $\mathrm{Y}$ & $\mathrm{Y}$ & $\mathrm{Y}$ & $\mathrm{Y}$ & $\mathrm{Y}$ & $\mathrm{Y}$ \\
\hline \multicolumn{14}{|c|}{ Produk } \\
\hline 1 & $\begin{array}{l}\text { Pengungkapan informasi pengembangan } \\
\text { produk perusahaan, termasuk } \\
\text { pengemasannya, }\end{array}$ & $\mathrm{Y}$ & $\mathrm{Y}$ & $\mathrm{Y}$ & $\mathrm{Y}$ & $\mathrm{Y}$ & $\mathrm{Y}$ & Y & $\mathrm{Y}$ & $\mathrm{Y}$ & $\mathrm{Y}$ & $\mathrm{Y}$ & $\mathrm{Y}$ \\
\hline 2 & $\begin{array}{l}\text { Gambaran pengeluaran riset dan } \\
\text { pengembangan produk; }\end{array}$ & $\mathrm{Y}$ & $\mathrm{Y}$ & $\mathrm{Y}$ & $\mathrm{Y}$ & $\mathrm{Y}$ & $\mathrm{Y}$ & $\mathrm{Y}$ & $\mathrm{Y}$ & $\mathrm{Y}$ & $\mathrm{Y}$ & $\mathrm{Y}$ & $\mathrm{Y}$ \\
\hline 3 & $\begin{array}{l}\text { Pengungkapan informasi proyek riset } \\
\text { perusahaan untuk memperbaiki produk }\end{array}$ & $\mathrm{Y}$ & $\mathrm{Y}$ & $\mathrm{Y}$ & $\mathrm{Y}$ & $\mathrm{Y}$ & $\mathrm{Y}$ & $\mathrm{Y}$ & $\mathrm{Y}$ & $\mathrm{Y}$ & $\mathrm{Y}$ & $\mathrm{Y}$ & $\mathrm{Y}$ \\
\hline 4 & $\begin{array}{l}\text { Pengungkapan bahwa produk memenuhi } \\
\text { standard keselamatan; }\end{array}$ & $\mathrm{Y}$ & $\mathrm{Y}$ & $\mathrm{Y}$ & $\mathrm{Y}$ & $\mathrm{Y}$ & $\mathrm{Y}$ & $\mathrm{T}$ & $\mathrm{T}$ & $\mathrm{T}$ & $\mathrm{Y}$ & $\mathrm{Y}$ & $\mathrm{Y}$ \\
\hline 5 & $\begin{array}{l}\text { Membuat produk lebih aman untuk } \\
\text { konsumen; }\end{array}$ & $\mathrm{Y}$ & $\mathrm{Y}$ & $\mathrm{Y}$ & $\mathrm{Y}$ & $\mathrm{Y}$ & $\mathrm{Y}$ & $\mathrm{Y}$ & $\mathrm{Y}$ & $\mathrm{Y}$ & $\mathrm{Y}$ & $\mathrm{Y}$ & $\mathrm{Y}$ \\
\hline 6 & $\begin{array}{l}\text { Melaksanakan riset atas tingkat keselamatan } \\
\text { produk perusahaan }\end{array}$ & $\mathrm{Y}$ & $\mathrm{Y}$ & $\mathrm{Y}$ & $\mathrm{Y}$ & $\mathrm{Y}$ & $\mathrm{Y}$ & $\mathrm{T}$ & $\mathrm{Y}$ & $\mathrm{T}$ & $\mathrm{Y}$ & $\mathrm{Y}$ & $\mathrm{Y}$ \\
\hline 7 & $\begin{array}{l}\text { Pengungkapan peningkatan } \\
\text { kebersihan/kesehatan dalam pengolahan dan } \\
\text { penyiapan produk; }\end{array}$ & $\mathrm{Y}$ & $\mathrm{Y}$ & $\mathrm{Y}$ & $\mathrm{Y}$ & $\mathrm{Y}$ & $\mathrm{Y}$ & $\mathrm{Y}$ & $\mathrm{Y}$ & $\mathrm{T}$ & $\mathrm{Y}$ & $\mathrm{Y}$ & $\mathrm{Y}$ \\
\hline 8 & $\begin{array}{l}\text { Pengungkapan informasi atas keselamatan } \\
\text { produk perusahaan }\end{array}$ & $\mathrm{Y}$ & $\mathrm{Y}$ & $\mathrm{Y}$ & $\mathrm{Y}$ & $\mathrm{Y}$ & $\mathrm{Y}$ & $\mathrm{T}$ & $\mathrm{Y}$ & $\mathrm{T}$ & $\mathrm{Y}$ & $\mathrm{Y}$ & $\mathrm{Y}$ \\
\hline 9 & $\begin{array}{l}\text { Pengungkapan informasi mutu produk yang } \\
\text { dicerminkan dalam penerimaan penghargaan }\end{array}$ & $\mathrm{Y}$ & $\mathrm{Y}$ & $\mathrm{Y}$ & $\mathrm{Y}$ & $\mathrm{Y}$ & $\mathrm{Y}$ & $\mathrm{Y}$ & $\mathrm{Y}$ & $\mathrm{Y}$ & $\mathrm{Y}$ & $\mathrm{Y}$ & $\mathrm{Y}$ \\
\hline 10 & Informasi yang dapat diverifikasi bahwa mutu & $\mathrm{Y}$ & $\mathrm{Y}$ & $\mathrm{Y}$ & $\mathrm{Y}$ & $\mathrm{Y}$ & $\mathrm{Y}$ & $\mathrm{Y}$ & $\mathrm{Y}$ & $\mathrm{Y}$ & $\mathrm{Y}$ & $\mathrm{Y}$ & $\mathrm{Y}$ \\
\hline
\end{tabular}




\begin{tabular}{|c|c|c|c|c|c|c|c|c|c|c|c|c|c|}
\hline & produk telah meningkat (Misalnya ISO 9000). & & & & & & & & & & & & \\
\hline \multicolumn{14}{|c|}{ Keterlibatan Masyarakat } \\
\hline 1 & $\begin{array}{l}\text { Sumbangan tunai, produk, pelayanan untuk } \\
\text { mendukung aktivitas masyarakat, pendidikan } \\
\text { dan seni }\end{array}$ & $\mathrm{Y}$ & $\mathrm{Y}$ & $\mathrm{Y}$ & $\mathrm{Y}$ & $\mathrm{Y}$ & $\mathrm{Y}$ & $\mathrm{Y}$ & $\mathrm{Y}$ & $\mathrm{Y}$ & $\mathrm{Y}$ & $\mathrm{Y}$ & $\mathrm{Y}$ \\
\hline 2 & $\begin{array}{l}\text { Tenaga kerja paruh waktu (part-time } \\
\text { employment) dari mahasiswa/pelajar }\end{array}$ & $\mathrm{Y}$ & $\mathrm{Y}$ & $\mathrm{Y}$ & $\mathrm{Y}$ & $\mathrm{Y}$ & $\mathrm{Y}$ & $\mathrm{Y}$ & $\mathrm{Y}$ & $\mathrm{Y}$ & $\mathrm{Y}$ & $\mathrm{Y}$ & $\mathrm{Y}$ \\
\hline 3 & $\begin{array}{l}\text { Sebagai sponsor untuk proyek kesehatan } \\
\text { masyarakat; }\end{array}$ & $\mathrm{Y}$ & $\mathrm{Y}$ & $\mathrm{Y}$ & $\mathrm{Y}$ & $\mathrm{Y}$ & $\mathrm{Y}$ & $\mathrm{Y}$ & $\mathrm{Y}$ & $\mathrm{Y}$ & $\mathrm{Y}$ & $\mathrm{Y}$ & $\mathrm{Y}$ \\
\hline 4 & Membantu riset medis; & $\mathrm{Y}$ & $\mathrm{Y}$ & $\mathrm{Y}$ & $\mathrm{Y}$ & $\mathrm{Y}$ & $\mathrm{Y}$ & $\mathrm{Y}$ & $\mathrm{Y}$ & $\mathrm{Y}$ & $\mathrm{Y}$ & $\mathrm{Y}$ & $\mathrm{Y}$ \\
\hline 5 & $\begin{array}{l}\text { Sebagai sponsor untuk konferensi pendidikan, } \\
\text { seminar atau pameran seni }\end{array}$ & $\mathrm{Y}$ & $\mathrm{Y}$ & Y & $\mathrm{Y}$ & $\mathrm{Y}$ & $\mathrm{Y}$ & $\mathrm{Y}$ & $\mathrm{Y}$ & $\mathrm{Y}$ & $\mathrm{Y}$ & $\mathrm{Y}$ & $\mathrm{Y}$ \\
\hline 6 & Membiayai program beasiswa & $\mathrm{Y}$ & $\mathrm{Y}$ & $\mathrm{Y}$ & $\mathrm{Y}$ & $\mathrm{Y}$ & $\mathrm{Y}$ & $\mathrm{Y}$ & $\mathrm{Y}$ & $\mathrm{Y}$ & $\mathrm{Y}$ & $\mathrm{Y}$ & $\mathrm{Y}$ \\
\hline 7 & $\begin{array}{l}\text { Membuka fasilitas perusahaan untuk } \\
\text { masyarakat; }\end{array}$ & $\mathrm{Y}$ & $\mathrm{Y}$ & $\mathrm{Y}$ & $\mathrm{Y}$ & Y & $\mathrm{Y}$ & $\mathrm{Y}$ & $\mathrm{Y}$ & $\mathrm{Y}$ & Y & Y & $\mathrm{Y}$ \\
\hline 8 & Mensponsori kampanye nasional; & $\mathrm{Y}$ & $\mathrm{Y}$ & $\mathrm{Y}$ & $\mathrm{Y}$ & $\mathrm{Y}$ & $\mathrm{Y}$ & $\mathrm{Y}$ & $\mathrm{Y}$ & $\mathrm{Y}$ & $\mathrm{Y}$ & $\mathrm{Y}$ & $\mathrm{Y}$ \\
\hline 9 & Mendukung pengembangan industri local & $\mathrm{Y}$ & $\mathrm{Y}$ & $\mathrm{Y}$ & $\mathrm{Y}$ & $\mathrm{Y}$ & $\mathrm{Y}$ & $\mathrm{Y}$ & $\mathrm{Y}$ & $\mathrm{Y}$ & $\mathrm{Y}$ & $\mathrm{Y}$ & $\mathrm{Y}$ \\
\hline \multicolumn{14}{|c|}{ Umum } \\
\hline 1 & $\begin{array}{l}\text { Pengungkapan tujuan/kebijakan perusahaan } \\
\text { secara umum berkaitan dengan tanggung } \\
\text { jawab sosial perusahaan kepada masyarakat. }\end{array}$ & $\mathrm{Y}$ & $\mathrm{Y}$ & $\mathrm{Y}$ & $\mathrm{Y}$ & Y & $\mathrm{Y}$ & $\mathrm{Y}$ & $\mathrm{Y}$ & $\mathrm{Y}$ & Y & $\mathrm{Y}$ & $\mathrm{Y}$ \\
\hline \multirow[t]{2}{*}{2} & $\begin{array}{l}\text { Informasi berhubungan dengan tanggung } \\
\text { jawab sosial perusahaan selain yang } \\
\text { disebutkan di atas }\end{array}$ & $\mathrm{Y}$ & $\mathrm{Y}$ & $\mathrm{Y}$ & $\mathrm{Y}$ & $\mathrm{Y}$ & $\mathrm{Y}$ & $\mathrm{Y}$ & $\mathrm{Y}$ & $\mathrm{Y}$ & $\mathrm{Y}$ & $\mathrm{Y}$ & $\mathrm{Y}$ \\
\hline & Total item yang diharapkan diungkapkan & 73 & 73 & 78 & 71 & 78 & 73 & 64 & 67 & 63 & 67 & 78 & 78 \\
\hline
\end{tabular}

* untuk sektor Others dilakukan penyesuaian untuk masing-masing perusahaan

Keterangan:

$\mathrm{Y}=$ item yang diharapkan diungkapkan sektor bersangkutan

$\mathrm{T}=$ item yang tidak relevan untuk sektor bersangkutan

Sektor Industri

$1=$ Agriculture Forestry and Fishing

$2=$ Animal Feed and Husbandry

$3=$ Mining and Mining service

$4=$ Construction

$5=$ Manufacturing

$6=$ Transportation Service

7 = Communication
$8=$ Whole Sale and Retail Trade

$9=$ Banking, Credit Agencies Other than Bank, securities, Insurance and Real estate

$10=$ Hotel And Travel Service

$11=$ Holding and Other Investment $12=$ Others 